\title{
Small-scale distribution of metazoan meiofauna and sedimentary organic matter in subtidal sandy sediments (Mediterranean Sea)
}

\author{
Davide Moccia, ${ }^{*}$ Alessandro Cau, Maria Carmela Meloni, Antonio Pusceddu \\ Department of Life and Environmental Sciences, University of Cagliari, Via Fiorelli 1, 09126 Cagliari, Italy
}

\begin{abstract}
While variations in sedimentary organic matter (OM) quantity, biochemical composition and nutritional quality as well as in meiofaunal abundance and assemblage composition at the macro- and mesoscale are relatively well known, information about variations at the microscale is much scarcer. To shed some light on this issue, we tested the null hypothesis by which abundance and composition of the meiofaunal assemblages, and the quantity, biochemical composition and nutritional quality of sedimentary organic matter in coastal shallow environments do not vary within a frame of 1 $\mathrm{m}^{2}$. No significant variation within the frame emerged for OM quantity, nutritional quality, biochemical composition and the abundance of meiofaunal assemblages. On the other hand, the composition of meiofaunal assemblages varied significantly within the frame and exhibited a clear segregation of assemblages farther to the shore, as a likely result of local micro-hydrodynamic conditions. Spatial autocorrelation analysis revealed that lipid and protein sedimentary contents had a random distribution, whereas carbohydrate and biopolymeric $\mathrm{C}$ contents and meiofaunal total abundance were characterized by a patchy distribution, with discrete peaks within the sub-frame squares (ca. $\left.0.1 \mathrm{~m}^{2}\right)$. Phytopigments showed a spatial positive autocorrelation distribution, following the micro-hydrodynamic pattern, with patches larger than the sub-frame square, but smaller than the entire one $\left(1 \mathrm{~m}^{2}\right)$. Overall, our results suggest that, within $1 \mathrm{~m}^{2}$ of subtidal sandy sediments, three replicates could be sufficient to assess correctly OM attributes and the abundance of meiofauna, but could be possibly inadequate for assessing meiofaunal assemblages' composition at a finer scale $\left(<1 \mathrm{~m}^{2}\right)$.
\end{abstract}

\section{INTRODUCTION}

Most typically, the environment is spatially structured in relation to different and variable energy inputs, which altogether modulate the distribution of organisms in patches or gradients (Legendre and Fortin, 1989; Levin and Sibuet 2012; Woolley et al., 2016). Indeed, the typical non-random pattern of species or species assemblages' organization determines the aggregation into clumps or patches of abundance (Levin and Sibuet, 2012; Pinckney and Sandulli, 1990; Rex and Etter, 2010).

The patchy distribution of marine benthos is the result of many different factors, including, among the others, either abiotic (e.g., geomorphology, hydrodynamic conditions; Zeppilli et al., 2016) or biotic (e.g., resource availability, competition and predation; Denny et al., 2004) factors.

The knowledge about the complexity of natural habitats is essential to understand the characteristics of assemblages' patchy distribution (Legendre and Fortin, 1989). The heterogeneity of the physical environment contributes significantly to preserve the community diversity, as well as the diversity of biological processes and ecological interactions that can be observed at different points in space (Legendre and Fortin, 1989). For instance, in marine ecosystems, habitat spatial heterogeneity and discontinuity of the substrates can explain the heterogeneous distribution of meiofauna and the relationships between biodiversity and ecosystem functioning (Zeppilli et al., 2016).
The comparison between spatial models of distribution of consumers and their resources gives information about the trophic interactions and the scale at which these interactions occur (Sandulli and Pickney, 1999). The scales of the spatial variability of the marine benthos have been investigated since a long time. However, while the scales of spatial variability for macrobenthos are well known, those of meiofauna and prokaryotes are still matter of debate (Danovaro et al., 2001; Fontaneto and Hortal, 2012; Moens et al., 2013; Pusceddu et al., 2014; Prat et al., 2015).

Meiofauna show frequently an irregular distribution over different spatial scale (Moens et al., 2013; Cerca et al., 2018; Fontaneto, 2019;) Several causes have been indicated to explain this, in particular for microscale variations (i.e., centimeters), and include, among the others: hydrodynamics (Semprucci et al., 2011), biotic structures (Bianchelli et al., 2013), reproduction, predation, micro-topography (Raes et al., 2007 ), intraspecific interactions (Chandler and Flegger, 1987) and food resources (Semprucci et al., 2019). One of the potential food sources for meiofauna is represented by the sedimentary organic matter (OM), which also includes the fraction originating from the micro-algae. OM quantity and biochemical composition in marine sediments allows to determine the trophic state of the system (Dell'Anno et al., 2002; Pusceddu et al., 2004, 2009), i.e. the levels of potential food availability for the benthic consumers and, therefore, for the meiofauna (Pusceddu et al., 2007, 2011). 
To provide further insights on the spatial scales of variation of meiofauna, we analyzed the small-scale $\left(<1 \mathrm{~m}^{2}\right)$ variation in the abundance and composition of the meiofaunal assemblages, along with the OM quantity, biochemical composition and nutritional quality in subtidal sandy sediments. More in details, we tested the null hypothesis by which abundance and composition of the meiofaunal assemblage, OM quantity, biochemical composition and nutritional quality do not vary within a surface of $1 \mathrm{~m}^{2}$.

Finally, we investigated the small-scale spatial autocorrelation of the organic compounds in terms of phytopigment, protein, carbohydrate, lipid, biopolymeric $\mathrm{C}$ (BPC) contents and meiofaunal abundance to: i) analyze the heterogeneity and variability of the spatial distribution at their smallest spatial scale of distribution; ii) characterize their spatial patterns of variation, as an indication of the reliability of the sample size and replication.

\section{METHODS}

Sediment sampling was carried out at $50-\mathrm{cm}$ depth in a coastal sandy location of South Sardinia (Tyrrhenian sea, Mediterranean Sea) in May 2016. A $1 \times 1 \mathrm{~m}$ frame was placed on the sea bottom and divided into $3 \times 3$ squares (each one of $33 \times 33 \mathrm{~cm}$ size) for a total of $9 \mathrm{sub}$ frames (Fig. 1). From each of the 9 sub-frames, 6 replicated sediment cores (randomly placed) were collected manually using plexiglass corers $(4.7 \mathrm{~cm}$ internal diameter), of which three of them dedicated to the analysis of sediment organic matter, and three to the analysis of the meiofauna.

For the OM determinations, the first $2 \mathrm{~cm}$ of each sediment core were stored in Petri dishes at $-20^{\circ} \mathrm{C}$ until the analysis. Protein, carbohydrate and lipid contents were determined spectrophotometrically according to Danovaro (2010). For each biochemical assay, blanks were obtained using pre-calcinated sediments $\left(450^{\circ} \mathrm{C}\right.$ for $4 \mathrm{~h}$ ). All the analyses were performed in triplicate, with about $1 \mathrm{~g}$ of sediment per replicate. Carbohydrate, protein and lipid sedimentary contents were converted into carbon equivalents using the conversion factors of 0.40 , 0.49 and $0.75 \mathrm{mg} \mathrm{C} \mathrm{mg}^{-1}$, respectively, and their sum defined as biopolymeric C (BPC) (Fabiano et al., 1995). Phytopigments were extracted using $5 \mathrm{~mL}$ of $90 \%$ acetone (at $4^{\circ} \mathrm{C}$ in the dark for $12 \mathrm{~h}$ ) from $0.5 \mathrm{~g}$ sediment samples (Lorenzen and Jeffrey, 1980). Concentrations of chlorophyll- $a$ and phaeopigments, after acidification of extracts with $200 \mathrm{~mL} 0.1 \mathrm{~N} \mathrm{HCl}$, were determined fluorometrically (Danovaro, 2010). Total phytopigments concentrations were calculated as sum of chlorophyll- $a$ and phaeopigment concentrations. The algal $\mathrm{C}$ contribution to BPC was calculated as the percentage of phytopigment-to-BPC concentrations after converting the total phytopigment concentrations in to $\mathrm{C}$ equivalents using a mean value of $40 \mathrm{mg} \mathrm{C} \mathrm{mg}^{-1}$. This, the protein contribution to $\mathrm{BPC}$ and the protein to carbohydrate ratio were used as proxies for $\mathrm{OM}$ nutritional quality (Pusceddu et al., 2009, 2010).

The meiofauna was extracted by decantation (Heip et al., 1985) as the sediments were dominated by sand. Sediments were sieved through a $40 \mathrm{~mm}$ mesh. The filtered material was collected and stored in $50 \mathrm{~mL}$ jars, diluted with marine water and fixed by buffered formalin $(\mathrm{pH} 8.2$, $2 \%$ final solution; Higgins and Thiel, 1988). The major meiobenthic organisms were counted and classified per taxon under a stereomicroscope (25-50x magnification) after staining with Rose Bengal $\left(0.5 \mathrm{~g} \mathrm{~L}^{-1}\right)$. The number of individuals obtained from each core was normalized to $10 \mathrm{~cm}^{2}$.

A non-parametric permutational analyses of variance (PERMANOVA; Anderson, 2001) was performed to test for differences in organic matter quantity, biochemical composition and nutritional quality, as well as meiofauna abundance and taxonomic composition, within the $1 \mathrm{~m}^{2}$ frame.

Two different designs were used:

i) considering samples station randomly distributed within the frame as single source of variation;

ii) considering two main sources of variation: transect as fixed factor $(\mathrm{T}=3$ levels, parallel to the coast line and

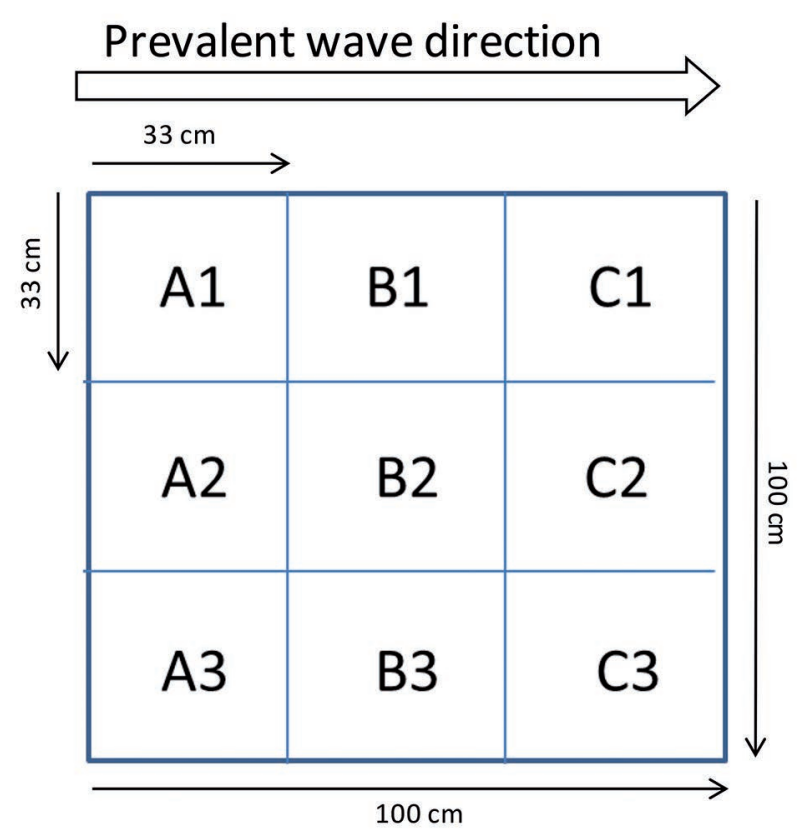

Fig. 1. Sampling design: the frame utilized in the present study is divided into 3 transects: $\mathrm{A}, \mathrm{B}$, and $\mathrm{C}$, with transect $\mathrm{A}$ on the coast side and transect $\mathrm{C}$ towards the sea. Numbers indicate the three stations in each of the three transect. 
perpendicular to the prevalent wave motion) and stations $(S=9)$ as random factor nested in $\mathrm{T}$.

The analysis of the OM dataset was based on Euclidean distances resemblance matrix of previously normalized data. The analysis of the meiofaunal dataset was based on: i) Bray-Curtis similarity matrix of either untransformed or presence/absence transformed data. The visual representation of the differences between stations/transects was obtained by a non-metric Multidimensional Scaling (nMDS). The use of presence/absence transformed data was chosen in order to scaling down the importance of highly abundant taxa (like nematodes) and, therefore, giving the same importance in variations to rare taxa (Anderson et al., 2001).

SIMPER analysis was performed to assess the percentage dissimilarity in the meiofaunal taxonomic composition between transects and sampling station to identify which species contributed most to the observed dissimilarities. The relative influence of the different biochemical compounds on variations in the composition of meiofaunal assemblages was investigated through a nonparametric multivariate multiple regression analysis using the routine DISTLM, with either untransformed and presence/absence transformed data. All statistical analyses were performed through the use of the software PRIMER $6+$, using the routine included in the package PERMANOVA (Anderson et al., 2008).

Small-scale dispersion analyses of sedimentary organic components (phytopigment, protein, carbohydrate, lipid and BPC concentrations) and meiofauna, were conducted using spatial autocorrelation techniques (Cliff and Ord, 1973; Sokal and Oden, 1978) to evaluate whether the observed spatial pattern of a variable is either random or aggregated so that the concentration/abundance value at one station is dependent on values present in neighboring station. In this analysis, Moran's Index, Geary's coefficient (weighting of distance ${ }^{-2}$, Jumars et al., 1977) and Fisher's Index $\left(\mathrm{s}^{2} / \mathrm{x}\right)$ were used to analyze spatial patterns. Moran's $I$, ranging between -1 (maximum negative autocorrelation) and +1 (maximum positive autocorrelation) was used to detect aggregation due to extreme values in adjacent cores. Geary's coefficient, ranging from 0 (maximum positive autocorrelation) to a positive value $(>1)$ for negative autocorrelation was used to test whether adjacent cores contain similar values (Jumars et al., 1977). When $I$ and $c$ are both significantly $>0$ the distribution reflects plain positive spatial autocorrelation, whereas when only $I$ is significant, the distribution creates discrete peaks in abundance. Furthermore, if $I, c$, and the Fisher's index are all not significant, the distribution is random (Pinckney and Sandulli, 1990), whereas if Fisher's index is significant but $I$ and $c$ are not, it means that the size of the aggregates is less than the sampling scale (Sokal and Wartenberg, 1981).

\section{RESULTS}

\section{Organic matter spatial variability}

Chlorophyll- $a$, phaeopigment, total phytopigment, protein, carbohydrate, lipid and biopolymeric $\mathrm{C}$ contents, as well as the algal and protein contributions to biopolymeric $\mathrm{C}$ and the protein to carbohydrate ratio, at all sampling stations are given in Tab. 1. The permutational analysis of variance was first ran considering sampling stations as unique source of variation. None of the organic compounds showed significant spatial variations (Tab. 2). The biopolymeric $\mathrm{C}$ content varied from $125.89 \pm 22.80$ to $186.92 \pm 53.85 \mu \mathrm{g} \mathrm{C} \mathrm{g}^{-1}$ (mean=154.95 $\pm 28.11 \mu \mathrm{g} \mathrm{C} \mathrm{g}^{-1}$; Fig. 2a). Carbohydrates (ranging from $217.87 \pm 36.05$ to $271.55 \pm 25.15 \mu \mathrm{g} \mathrm{g}^{-1}$ ) were the dominant organic compound with an average $63 \%$ contribution to the biopolymeric $\mathrm{C}$, followed by proteins (ranging from $68.33 \pm 16.95$ to $130.57 \pm 69.63 \mu \mathrm{g} \mathrm{g}^{-1}, 34 \%$ of BPC on average), and lipids (ranging from $3.37 \pm 0.81$ to $10.33 \pm 0.71 \mathrm{mg} \mathrm{g}^{-1} ; 3 \%$ of BPC on average, Fig. 2b).

Total phytopigments concentration (as the sum of chlorophyll- $a$ and phaeopigments) varied from $0.61 \pm 0.06$ to $1.00 \pm 0.49 \mu \mathrm{g} \mathrm{g}^{-1}$, with a general dominance of chlorophyll- $a$ (up to $0.77 \pm 0.36 \mu \mathrm{g} \mathrm{g}^{-1}$, average of $79 \%$ of total phytopigments) over phaeopigments (maximum value $0.23 \pm 0.13$, average of $21 \%$ ) (Fig. $2 \mathrm{c}$ ). Biochemical composition and nutritional quality of sedimentary organic matter did not vary among stations as a whole (Tab. 2).

\section{Spatial variability of meiofauna}

Overall, a total of 9 major taxa were found within the 1 $\mathrm{m}^{-2}$ sampling frame: Nematoda, Amphipoda, Copepoda, Gastropoda, Gastrotricha, Oligochaeta, Ostracoda, Polychaeta and Tardigrada, six out of which were ubiquitous in all the sampling stations (nematodes, amphipods, copepods, gastropods, gastrotriches and ostracods). Polychaetes were only encountered within stations along the transects A and $\mathrm{B}$, oligochaetes were encountered exclusively in stations along transect $\mathrm{B}$ and Tardigrades were exclusively encountered in stations along transect A (Tab. 3). The total abundance of meiofauna showed no significant variation within the frame (Tab. 4a; Fig. 3a). Differently, the composition of the meiofaunal assemblages (using either untransformed or presence/absence transformed data) significantly varied within the frame when sample stations were considered as the only source of variation (Tab. 4a; Fig. 3b). When two factors of variation were considered, transects $(\mathrm{A}, \mathrm{B}, \mathrm{C})$ and stations $(1,2,3)$, the analysis of variation based on untransformed data showed the presence of significant spatial variations only among transects (Tab. 4b). When the analysis was conducted on presence/absence transformed data, the differences were significant only among stations within each transect (Tab. 4b). A higher nematode dominance (av- 


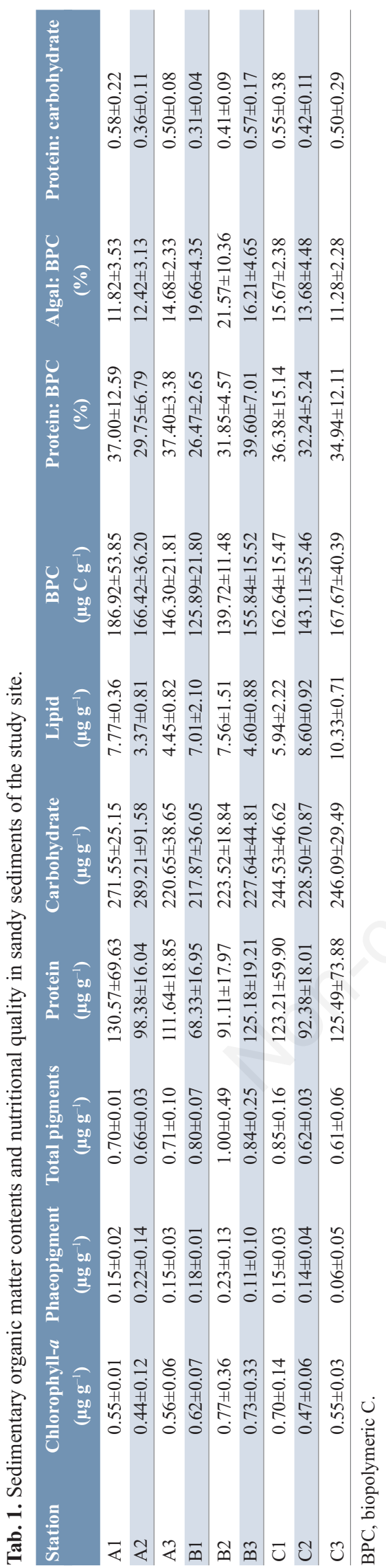

erage of $90 \%$ of the total meiofaunal abundance) occurred in transect A, when compared to the other two transects (ca. $85 \%$ in both transect $B$ and C). The abundance of copepods and gastrotrichs increased, from an average of 5\% and $0.1 \%$ in transect $\mathrm{A}$, to an average of $10 \%$ and $0.8 \%$ in transect $\mathrm{C}$, respectively (Fig. 3b). This pattern was further confirmed by the SIMPER analysis, that reveals that differences in the relative abundance of nematodes and copepods were the most responsible for the observed spatial dissimilarities. The SIMPER analysis also reveals that the larger dissimilarities in the composition of meiofaunal assemblages occurred between transect $\mathrm{C}$ and the other two transects (Tab. 5). Variation among the three transects was also confirmed by the nMDS bi-plot, that shows a clear visual segregation between transect $\mathrm{C}$ and the other two transects (Fig. 4).

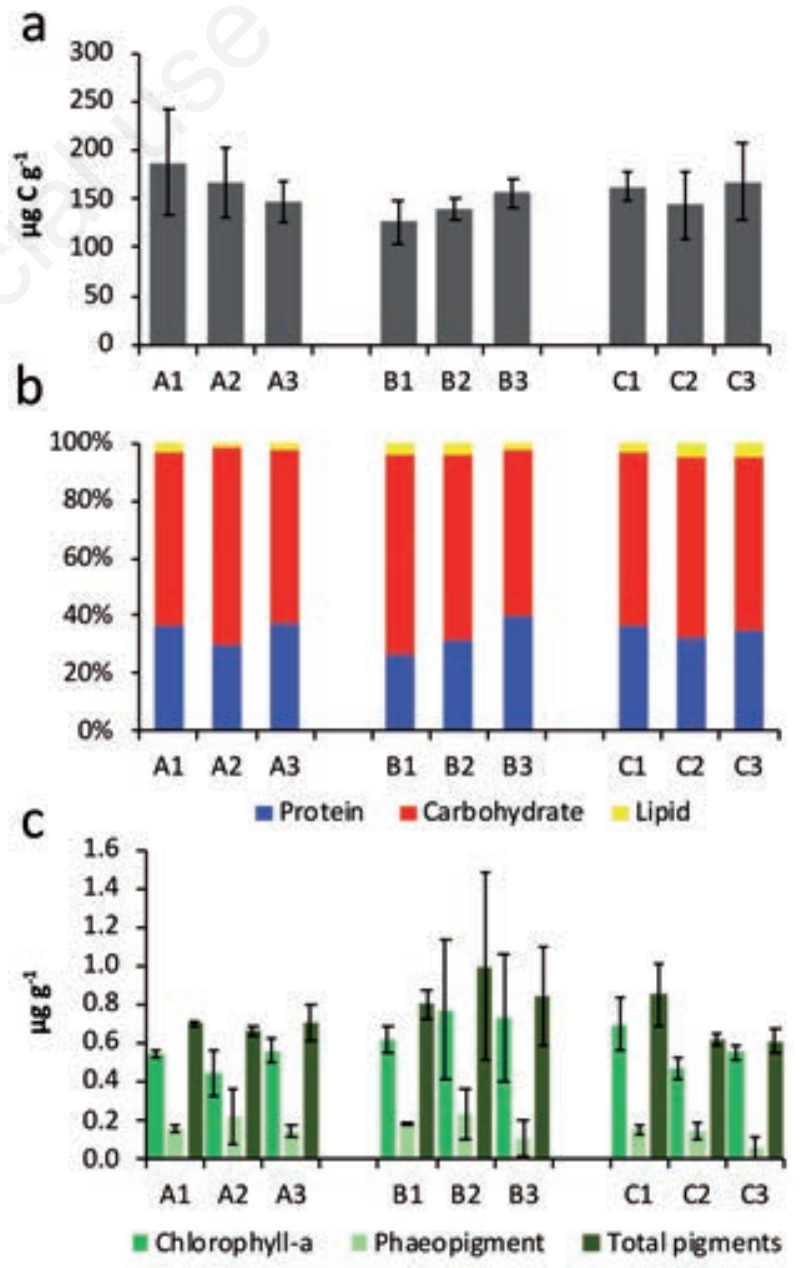

Fig. 2. Sedimentary organic matter contents and biochemical composition in the investigated sediments. a) biopolymeric $\mathrm{C}$ content, b) protein, carbohydrate and lipid contribution to biopolymeric $\mathrm{C}, \mathrm{c}$ ) chlorophyll- $a$, phaeopigment and total phytopigment contents. 


\section{Organic matter-meiofauna relationships}

The results of the DISTLM forward analysis reveals that lipids and phaeopigments explained $37 \%$ and $22 \%$, respectively, of meiofaunal assemblage variations, when the analysis was run on untransformed data, whereas, when the analysis was carried out on presence/absence data, lipids and proteins explained $41 \%$ and $27 \%$ of variation.

Tab. 2. Results of the PERMANOVA testing for differences among stations in the composition and the nutritional quality of sedimentary organic matter in $1 \mathrm{~m}^{2}$ of subtidal sandy sediments. Reported is also the percentage of variance explained by the source of variation (station).

\begin{tabular}{llllllc} 
Variable & Source & df & MS & Pseudo F & P (MC) & \% of explained variance \\
Protein & Station & 8 & 0.884 & 0.841 & $\mathrm{~ns}$ & 60 \\
Carbohydrate & Station & 8 & 1.117 & 1.179 & $\mathrm{~ns}$ & 6 \\
\hline Lipid & Station & 8 & 1.806 & 2.813 & $\mathrm{~ns}$ & 38 \\
Biopolymeric C & Station & 8 & 1.309 & 1.517 & $\mathrm{~ns}$ & 15 \\
\hline Chlorophyll- $a$ & Station & 8 & 1.194 & 1.307 & $\mathrm{~ns}$ & 9 \\
Phaeopigment & Station & 8 & 1.231 & 1.372 & $\mathrm{~ns}$ & 11 \\
\hline Total phytopigments & Station & 8 & 1.212 & 1.339 & $\mathrm{~ns}$ & 10 \\
Protein: carbohydrate & Station & 8 & 0.625 & 0.533 & $\mathrm{~ns}$ & 0 \\
\hline Protein fraction of BPC & Station & 8 & 0.742 & 0.664 & $\mathrm{~ns}$ & 0 \\
Algal fraction of BPC & Station & 8 & 1.481 & 1.882 & $\mathrm{~ns}$ & $\mathrm{~ns}$ \\
\hline Biochemical composition & Station & 8 & 5.016 & 1.416 & $\mathrm{~ns}$ & 0 \\
\hline
\end{tabular}

df, degrees of freedom; MS, means square; F, statistic F; P (MC), Monte Carlo probability level; BPC, biopolymeric C; ns, not significant.

Tab. 3. Meiofaunal abundance (numbers of individuals per $10 \mathrm{~cm}^{2} \pm$ standard error) in the sandy sediment of the study site.

\begin{tabular}{lccccccccc} 
Station & Nematodes & Amphipods & Copepods & Gasteropods & Gastrotrichs & Oligochaetes & Ostracods & Polychaetes & Tardigrades \\
A1 & $2247 \pm 187$ & $91 \pm 38$ & $122 \pm 31$ & $5 \pm 3$ & $5 \pm 2$ & 0 & $5 \pm 33$ & $3 \pm 2$ & 0 \\
A2 & $2626 \pm 446$ & $106 \pm 13$ & $128 \pm 18$ & $17 \pm 6$ & $3 \pm 2$ & 0 & $14 \pm 5$ & $1 \pm 1$ & $1 \pm 0$ \\
\hline A3 & $2302 \pm 133$ & $167 \pm 15$ & $168 \pm 26$ & $13 \pm 5$ & $1 \pm 1$ & 0 & $13 \pm 6$ & 0 & 0 \\
B1 & $2920 \pm 121$ & $170 \pm 21$ & $154 \pm 4$ & $21 \pm 3$ & $2 \pm 2$ & $2 \pm 0$ & $4 \pm 1$ & 0 & 0 \\
\hline B2 & $1875 \pm 197$ & $138 \pm 31$ & $103 \pm 23$ & $13 \pm 3$ & $12 \pm 1$ & 0 & $3 \pm 1$ & $2 \pm 2$ & 0 \\
B3 & $2146 \pm 336$ & $140 \pm 32$ & $139 \pm 42$ & $8 \pm 2$ & $22 \pm 7$ & $1 \pm 1$ & $3 \pm 1$ & $1 \pm 1$ & 0 \\
\hline C1 & $2611 \pm 231$ & $161 \pm 28$ & $310 \pm 29$ & $3 \pm 3$ & $36 \pm 4$ & 0 & $4 \pm 2$ & 0 & 0 \\
C2 & $2109 \pm 204$ & $121 \pm 13$ & $253 \pm 10$ & $1 \pm 1$ & $20 \pm 5$ & 0 & $3 \pm 2$ & 0 & 0 \\
\hline C3 & $3612 \pm 386$ & $128 \pm 16$ & $238 \pm 15$ & $0 \pm 0$ & $15 \pm 1$ & 0 & $3 \pm 1$ & 0 & 0 \\
\hline
\end{tabular}

Tab. 4. Results of the PERMANOVA testing for: a) differences among stations (one factor design) and b) differences among transects ( Tr) and stations (St) (two factors design) in the abundance and composition (using untransformed and presence/absence transformed data, respectively) of the meiofaunal assemblages. Also reported is the percentage of variance explained by each source of variation.

\begin{tabular}{|c|c|c|c|c|c|c|}
\hline $\begin{array}{l}\text { a) One factor design } \\
\text { Variable }\end{array}$ & Source & df & MS & Pseudo F & P(MC) & $\begin{array}{c}\% \text { of explained } \\
\text { variance }\end{array}$ \\
\hline Total meiofaunal abundance & Station & 8 & 165.4 & 2.037 & ns & 24 \\
\hline Assemblage composition(untransformed data) & Station & 8 & 202.5 & 2.096 & * & 29 \\
\hline Community composition (presence/absence transformed data) & Station & 8 & 214.3 & 3.165 & $* *$ & 41 \\
\hline $\begin{array}{l}\text { b) Two factors design } \\
\text { Variable }\end{array}$ & Source & df & MS & Pseudo F & $\mathbf{P}(\mathbf{M C})$ & $\begin{array}{l}\% \text { of explained } \\
\text { variance }\end{array}$ \\
\hline Assemblage composition (untransformed data) & $\begin{array}{c}\operatorname{Tr} \\
\text { St (Tr) }\end{array}$ & $\begin{array}{l}2 \\
6\end{array}$ & $\begin{array}{c}342.9 \\
95.4\end{array}$ & $\begin{array}{l}3.596 \\
2.263\end{array}$ & $\begin{array}{c}* \\
\mathrm{~ns}\end{array}$ & $\begin{array}{l}31 \\
20\end{array}$ \\
\hline Assemblage composition (presence/absence transformed data) & $\operatorname{Tr}$ & 2 & 370.8 & 1.909 & ns & 28 \\
\hline & $\mathrm{St}(\mathrm{Tr})$ & 6 & 194.3 & 3.005 & $* *$ & 34 \\
\hline
\end{tabular}

df, degrees of freedom; MS, means square; F, statistic F; P (MC), Monte Carlo probability level; BPC, biopolymeric $\mathrm{C} ;{ }^{* * * *} \mathrm{P}<0.001 ;{ }^{* * *} \mathrm{P}<0.01 ;{ }^{*} \mathrm{P}<0.05$, ns, not significant. 


\section{Spatial autocorrelation analyses and surface plots}

The results of the autocorrelation analysis are reported in Tab. 6, Moran's I, Geary's c, and Fisher's index were determined for all variables. Results showed that within $1 \mathrm{~m}^{2}$ sampling area, proteins and lipids showed a random spatial distribution ( $I, c$ and Fisher's index $\mathrm{p}>0.05$, Tab. 6 ), whereas carbohydrates, biopolymeric $\mathrm{C}$ and meiofaunal total abundance exhibited a patchy distribution, with patches smaller than $1 \mathrm{~m}^{2}$, since $I$ and $c$ do not depart significantly from 1 , but Fisher's index is significantly $>1$ (Tab. 6). Only chlorophyll- $a$ and phaeopigment showed a positive auto-correlated pattern $(\mathrm{I}=0.34, \mathrm{p}<0.05 \mathrm{c}=0.52$, $\mathrm{p}<0.05 ; \mathrm{I}=0.34 \mathrm{p}<0.05 \mathrm{c}=0.58 \mathrm{p}<0.05)$ with patch size larger than the single sampling square $\left(0.1 \mathrm{~m}^{2}\right)$, but lower than the total sampling area $\left(1 \mathrm{~m}^{2}\right)$ (Tab. 6).

\section{DISCUSSION AND CONCLUSIONS}

A detailed understanding of the spatial distribution patterns of consumers and their resources and the scale at which their interactions occur is essential to assess a correct and reliable size of samples (Sandulli and Pickney, 1999, Semprucci et al., 2011). An inappropriate sample size, indeed, may lead to under- or over-estimate spatial heterogeneity and, thus, to formulate erroneous conclusions (Cerca et al., 2018). In this study, we analyzed the small-scale variation of the meiofauna assemblages (in terms of either abundance and taxonomic composition) and the quantity, nutritional quality and biochemical composition of OM in subtidal sediments, to test the hypoth- esis by which meiofaunal assemblages and OM quantity and composition do not vary within a surface of $1 \mathrm{~m}^{2}$.

Our results show that sediments under scrutiny were characterized by a generally homogeneous spatial distri-

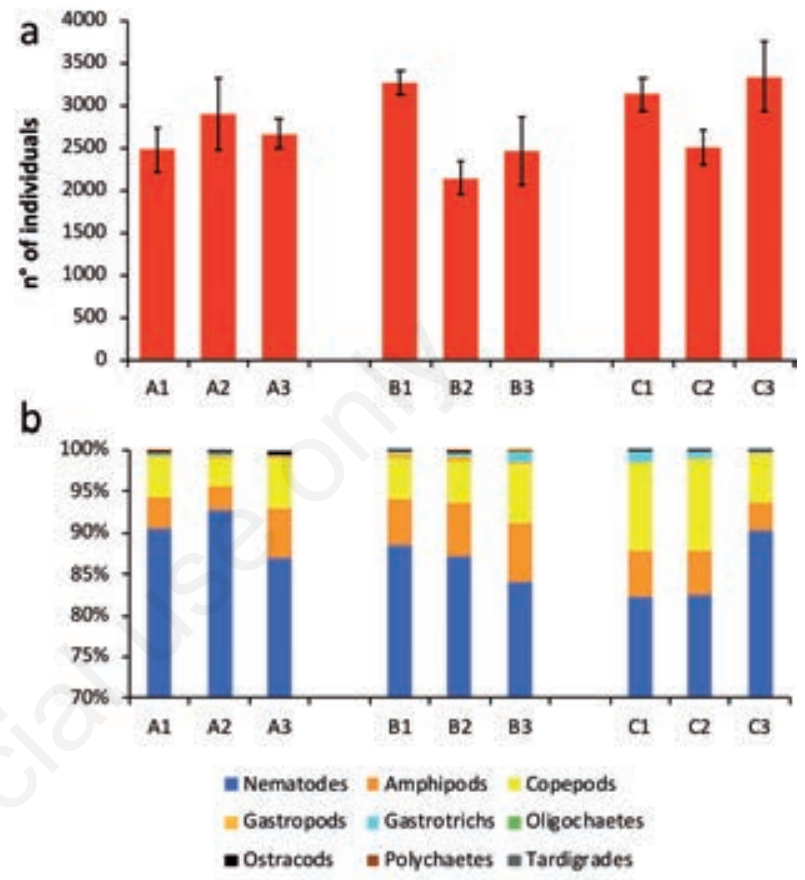

Fig. 3. Total meiofauna abundance (a) and assemblage composition (b) in transects and stations of the investigated sediments.

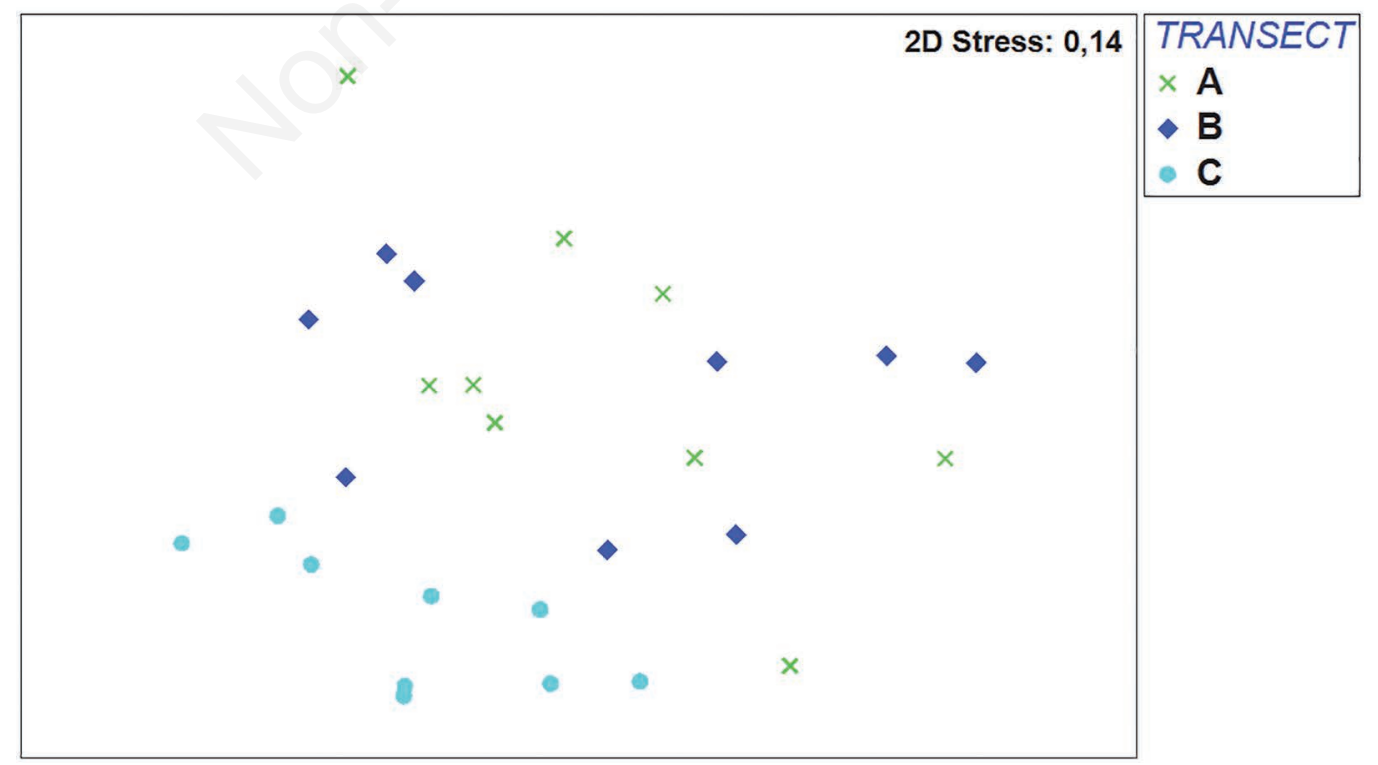

Fig. 4. nMDS ordination of meiofauna assemblage data in the investigated sediments. 
bution of the trophic conditions, in terms of OM quantity, biochemical composition and nutritional quality. A similar homogeneous distribution pattern at the small scale (i.e., within $1 \mathrm{~m}^{2}$ ) emerged also for the meiofaunal total abundance. These results, corroborated by the lack of autocorrelation patterns, indicate that the collection of 3 random replicas within a $1 \mathrm{~m}^{2}$ frame can be enough to represent reliably the mean characteristics of either OM or meiofaunal abundance within such a spatial scale.

On the other hand, the significant variation (PERMANOVA $\mathrm{P}<0.05$ ) of the meiofaunal community compo- sition among the three transects at this small spatial scale $\left(1 \mathrm{~m}^{2}\right)$, indicates that the sampling effort for assessing the variability of meiofaunal assemblage composition in sandy shallow sediments exposed to wave action would need a higher number of (possibly larger) replica per single $\mathrm{m}^{2}$.

In this regard, we showed that changes in the composition of the meiofaunal assemblages across transects were associated with variations in the micro-hydrodynamic gradient, which decreased from transect $\mathrm{A}$ (nearest to the coast) and the transect $\mathrm{C}$. Although. our experiment is limited to the spring season, and thus not exportable on

Tab. 5. Dissimilarities in the composition of meiofaunal assemblages among transects and stations and species responsible for the estimated difference.

\begin{tabular}{|c|c|c|c|c|}
\hline & Dissimilarity (\%) & Explanatory species & Explained variance (\%) & Cumulative explained variance $(\%)$ \\
\hline Transect A $v s \mathrm{~B}$ & 10.50 & Nematodes, Amphipods & $34.79,14.70$ & 49.49 \\
\hline Transect $\mathrm{A} v s \mathrm{C}$ & 12.64 & Nematodes, Copepods & $26.30,22.56$ & 48.48 \\
\hline Transect B vs C & 12.49 & Nematodes, Copepods & $33.14,24.89$ & 58.03 \\
\hline A1 vs A2 & 16.06 & Polychaetes, Gasteropods & $28.55,18.35$ & 46.90 \\
\hline A1 vs A3 & 18.50 & Gastrotrichs, Polychaetes & $32.95,32.11$ & 65.05 \\
\hline A2 vs A3 & 10.45 & Gastrotrichs, Tardigrades & $45.91,28.19$ & 74.10 \\
\hline $\mathrm{A} 1 v s \mathrm{~B} 1$ & 25.08 & Oligochaetes, Gastrotrichs & $32.52,22.26$ & 54.78 \\
\hline $\mathrm{B} 2 v s \mathrm{~B} 1$ & 17.54 & Oligochaetes, Gastrotrichs & $45.13,25.17$ & 70.30 \\
\hline $\mathrm{A} 3$ vs B1 & 12.30 & Oligochaetes, Gastrotrichs & $68.52,31.48$ & 100 \\
\hline $\mathrm{A} 1 v s \mathrm{~B} 2$ & 10.48 & Polychaetes, Gasteropods & $50.00,34.19$ & 84.19 \\
\hline $\mathrm{A} 2$ vs B2 & 8.83 & Polychaetes, Gastrotrichs & $38.71,30.65$ & 69.35 \\
\hline A3 vs B2 & 8.60 & Gastrotrichs, Polychaetes & $68.52,31.48$ & 100 \\
\hline $\mathrm{B} 1 v s \mathrm{~B} 2$ & 15.83 & Oligochaetes, Gastrotrichs & $50.00,34.14$ & 84.19 \\
\hline A1 vs B3 & 12.66 & Polychaetes, Gasteropods & $35.72,22.70$ & 58.43 \\
\hline $\mathrm{A} 2$ vs B3 & 10.92 & Polychaetes, Gastrotrichs & $30.20,24.24$ & 54.44 \\
\hline A3 vs B3 & 10.76 & Oligochaetes, Gastrotrichs & $53.46,23.27$ & 76.73 \\
\hline $\mathrm{B} 1 v_{s} \mathrm{~B} 3$ & 13.03 & Oligochaetes, Gastrotrichs & $41.54,40.60$ & 82.14 \\
\hline $\mathrm{B} 2 v s \mathrm{~B} 3$ & 5.62 & Polychaetes, Oligochaetes & $58.61,41.39$ & 100 \\
\hline $\mathrm{A} 1$ vs $\mathrm{C} 1$ & 12.85 & Polychaetes, Gasteropods & $44.86,30.78$ & 75.64 \\
\hline $\mathrm{A} 2$ vs $\mathrm{C} 1$ & 11.31 & Gasteropods, Gastrotrichs & $26.06,25.32$ & 51.37 \\
\hline A3 vs $\mathrm{C} 1$ & 9.49 & Gastrotrichs, Gasteropods & $65.69,34.04$ & 100 \\
\hline $\mathrm{B} 1$ vs $\mathrm{C} 1$ & 17.03 & Oligochaetes, Gastrotrichs & $49.09,33.61$ & 82.70 \\
\hline $\mathrm{B} 2$ vs $\mathrm{C} 1$ & 5.58 & Gasteropods, Polychaetes & $52.78,47.22$ & 100 \\
\hline $\mathrm{B} 3$ vs $\mathrm{C} 1$ & 7.76 & Gasteropods, Oligochaetes & $37.05,31.47$ & 68.53 \\
\hline $\mathrm{A} 1$ vs $\mathrm{C} 2$ & 14.05 & Polychaetes, Gasteropods & $42.26,28.87$ & 71.13 \\
\hline $\mathrm{A} 2$ vs $\mathrm{C} 2$ & 14.49 & Gasteropods, Gastrotrichs & $20.33,20.33$ & 40.66 \\
\hline $\mathrm{A} 3$ vs $\mathrm{C} 2$ & 12.93 & Gastrotrichs, Gasteropods & $50.00,25.00$ & 75.00 \\
\hline $\mathrm{B} 1 v s \mathrm{C} 2$ & 20.38 & Oligochaetes, Gastrotrichs & $42.19,28.91$ & 71.09 \\
\hline $\mathrm{B} 2$ vs $\mathrm{C} 2$ & 8.60 & Gasteropods, Ostracods & $34.26,34.26$ & 68.52 \\
\hline $\mathrm{B} 3$ vs $\mathrm{C} 2$ & 10.76 & Gasteropods, Ostracods & $26.73,26.73$ & 53.46 \\
\hline $\mathrm{C} 1$ vs $\mathrm{C} 2$ & 7.27 & Gasteropods, Ostracods & $56.94,43.06$ & 100 \\
\hline A1 vs C3 & 15.25 & Polychaetes, Gasteropods & $40.07,38.08$ & 78.15 \\
\hline $\mathrm{A} 2$ vs C3 & 17.68 & Gasteropods, Gastrotrichs & $50.00,17.14$ & 67.14 \\
\hline $\mathrm{A} 3$ vs $\mathrm{C} 3$ & 16.36 & Gasteropods, Gastrotrichs & $59.26,40,74$ & 100 \\
\hline $\mathrm{B} 1 v_{s} \mathrm{C} 3$ & 23.74 & Gasteropods, Oligochaetes & $37.23,37.23$ & 74.47 \\
\hline $\mathrm{B} 2 v s \mathrm{C} 3$ & 11.62 & Gasteropods, Polychaetes & $76.09,23.91$ & 100 \\
\hline $\mathrm{B} 3$ vs C3 & 13.75 & Gasteropods, Oligochaetes & $62.71,18.64$ & 81.36 \\
\hline $\mathrm{C} 1$ vs $\mathrm{C} 3$ & 6.06 & Gasteropods & 100 & 100 \\
\hline $\mathrm{C} 2$ vs $\mathrm{C} 3$ & 9.70 & Gasteropods, Ostracods & $65.63,34.38$ & 100 \\
\hline
\end{tabular}


Tab. 6. Results of spatial autocorrelation analyses of all variables. Moran's I, Geary's c, and Fisher's index are reported. Autocorrelation values were calculated using weighting of distance ${ }^{-2}$ and significant values were assigned using the randomization assumption. Expected values $E(I)=-0.020$ and $E(c)=1.000$.

\begin{tabular}{|c|c|c|c|c|c|c|}
\hline Variable & \multicolumn{2}{|c|}{ Moran's I } & \multicolumn{2}{|c|}{ Geary's c } & \multicolumn{2}{|c|}{ Fisher's Index } \\
\hline Proteins & -0.33 & ns & 1.25 & ns & 4.12 & ns \\
\hline Carbohydrates & -0.06 & ns & 0.80 & ns & 102.66 & $* * *$ \\
\hline Lipid & -0.16 & ns & 0.96 & ns & 0.75 & ns \\
\hline Biopolymeric C & -0.13 & ns & 1.00 & ns & 7.09 & $* * *$ \\
\hline Chlorophyll- $a$ & 0.34 & $*$ & 0.52 & $*$ & 0.02 & ns \\
\hline Phaeopigments & 0.34 & $*$ & 0.58 & $*$ & 0.01 & ns \\
\hline Meiofauna & -0.26 & ns & 1.08 & ns & 62.3 & $* * *$ \\
\hline
\end{tabular}

${ }^{*} \mathrm{P}<0.05 ;{ }^{* *} \mathrm{P}<0.01 ;{ }^{* * *} \mathrm{P}<0.001 ;$ ns, not significant.

wider temporal scales, we notice that, across such gradient, the abundance of copepods and amphipods increased, whereas that of nematodes decreased. Such a pattern is consistent with the habitus of these taxa (Higgins and Thiel, 1988; Thiel, 1992; Giere, 2009): copepods have a preeminent epi-benthic habitus, so that they are more sensitive to higher hydrodynamic conditions (where waves break), where, instead, nematodes, with a preeminent infaunal habitus, can easily dig the sediment to resist to waves' disturbance. Moreover, several nematodes species are capable of adhering to the sediment particles thanks to a gland that secretes sticky mucus, forming an "armature" that increases their body weight and, thereby, their resistance to the hydrodynamic disturbance (Moens et al., 2013). The response of nematodes to hydrodynamic action (waves and currents) have been observed also in tropical areas (Maldives), in which the effect of the higher exposition to the monsoon shaped the meiofaunal assemblages showing a higher nematodes abundance in exposed areas compared to those exposed to from low to medium physical disturbance (Semprucci et al., 2010, 2011). Although the sediment grain size variation within $1 \mathrm{~m}^{2}$ in a microtidal area, like the one under scrutiny can be assumed to be invariant, another potential bias of our results remains the lack of data about sediment grain size, which typically responds to physical disturbance and, in turn, represents a major factor controlling distribution of meiofauna (Semprucci et al., 2010).

The analyses carried out to identify the type of spatial pattern (random or patchy) of the investigated variables indicate that carbohydrate concentration, BPC and total meiofaunal abundance showed a patchy distribution, as previously reported also for bacteria and other biopolymers in sandy sediments of the Adriatic Sea (Danovaro et al., 2001). The significant Fisher's index indicates also that for all of those variables the patch size was smaller than the surface of two adjacent squares (ca. $<0.2 \mathrm{~m}^{2}$ ). On the other hand, chlorophyll- $a$ and phaeopigments (which typically represent the most important nutritional compo- nent of sedimentary OM, even in the deep sea; Bianchelli et al., 2008; Pusceddu et al., 2009) revealed a patchy distribution characterized by patch sizes higher than a single sub-frame square (i.e., $>0.1 \mathrm{~m}^{2}$ ). In particular, chlorophyll- $a$ sedimentary contents slightly increased while moving far from the shore. One possible explanation for such a pattern is that microalgal patch size might be influenced by the micro-scale hydrodynamic features which, in turn, shape the bottom micro-topography. This latter hypothesis is consistent with previous findings from micro-scale distribution analyses (Danovaro et al., 2001), that identified sandy ripples and marks as the sedimentary structures - shaped by waves motion in shallow waters that are most responsible for the micro-distribution patterns of benthic phytopigments. We stress that the microalgal patch size reported in this study $\left(<0.1 \mathrm{~m}^{2}\right)$ could be up to two orders of magnitude larger than that reported in Adriatic sediments $\left(1.34 \mathrm{~cm}^{2}\right)$. We notice, however, that such a huge discrepancy could be due to the much different size of the sub-frame square used in this study when compared to that used by Danovaro et al., (2001), who analyzed samples collected centimeters one a part to assess the micro-topographical significance of ripplesmarks structures and the depression among them.

Many studies have shown that the composition of meiofaunal communities depends upon the quantity and biochemical composition of sedimentary organic matter over a broad range of spatial scales and habitats (Cerrano et al., 2010; Pusceddu et al., 2007, 2011; Semprucci et al., 2010; Bianchelli et al., 2013). Among the different classes of organic compounds, phytopigments, proteins and lipids often represent high-energy components of the biopolymeric C (Pusceddu et al., 2009) and, indeed, have been often related to meiofaunal abundance and biodiversity either in shallow (Albertelli et al., 1999) and deepsea (Danovaro et al., 1999; Gambi et al., 2014) habitats. Most typically, algal and protein fractions of biopolymeric $\mathrm{C}$ represent the most bioavailable components for benthic consumers nutrition (Pusceddu et al., 2003). Accordingly, 
the results of the DISTLM analysis carried out in this study suggest that the spatial variation of meiofauna even at the small scale considered here - is tightly related to the concentration of lipids and phaeopigments (meiofaunal abundance) or proteins (community composition).

Corresponding author: mocciadavide@unica.it

Key words: Biochemical composition; nutritional quality; spatial variability; sampling size; coastal content; trophic status.

Received: 14 March 2019

Accepted: 21 June 2019

This work is licensed under a Creative Commons Attribution NonCommercial 4.0 License (CC BY-NC 4.0).

${ }^{\circ}$ Copyright: the Author(s), 2019

Licensee PAGEPress, Italy

Advances in Oceanography and Limnology, 2019; 10:8169

DOI: 10.4081/aiol.2019.8169

\section{REFERENCES}

Albertelli G, Covazzi-Harriague A, Danovaro R, Fabiano M, Fraschetti S, Pusceddu A, 1999. Differential responses of bacteria, meiofauna and macrofauna in a shelf area (Ligurian Sea, NW Mediterranean): Role of food availability. J. Sea. Res. 42:11-26.

Anderson MJ, 2001. Permutation tests for univariate or multivariate analysis of variance and regression. Can. J. Fish. Aquat. Sci. 58:626-639.

Anderson MJ, Gorley RN, Clarke KR, 2008. PERMANOVA+ for PRIMER: guide to software and statistical methods. PRIMER-E: Plymouth, UK.

Bianchelli S, Gambi C, Pusceddu A, Danovaro R, 2008. Trophic conditions and meiofaunal assemblages in the Bari Canyon and the adjacent open slope (Adriatic Sea). Chem. Ecol. 24:101-109.

Bianchelli S, Pusceddu A, Canese S, Greco S, Danovaro R, 2013. High meiofaunal and nematodes diversity around mesophotic coral oases in the Mediterranean Sea. PLoS One 8:e66553.

Blanchard GF, 1990. Overlapping microscale dispersion patterns of meiofauna and microphytobethos. Mar. Ecol. Prog. Ser. 68:101-111.

Cerca J, Purschke G, Struck TH, 2018. Marine connectivity dynamics: clarifying cosmopolitan distributions of marine interstitial invertebrates and the meiofauna paradox. Mar. Biol. 165:1-21.

Cerrano C, Danovaro R, Gambi C, Pusceddu A, Riva A, Schiaparelli S, 2010. Gold coral (Savalia savaglia) and gorgonian forests enhance benthic biodiversity and ecosystem functioning in the mesophotic zone. Biodivers. Conserv. 19:153-167.

Chandler GT, Fleeger JW, 1987. Facilitative and inhibitory interactions among estuarine meiobenthic harpacticoid copepods. Ecology 68:1906-1919.

Cliff A, Ord J, 1973. Spatial autocorrelation. London: Pion.
Danovaro R, 2010. Methods for the study of deep-sea sediments, their functioning and biodiversity. CRC Press, Taylor \& Francis Group, Boca Raton.

Danovaro R, Armeni M, Dell'Anno A, Fabiano M, Manini E, Marrale D, Pusceddu A, Vanucci S, 2001. Small-scale distribution of bacteria, enzymatic activities and organic matter in coastal sediments. Microb. Ecol. 42:177-185.

Danovaro R, Dinet A, Duineveld G, Tselepides A, 1999. Benthic response to particulate fluxes in different trophic environments: a comparison between the Gulf of Lions Catalan Sea (Western-Mediterranean) and the Cretan Sea (Eastern-Mediterranean). Prog. Oceanogr. 44:287-312.

Decho AW, Hummon WD, Fleeger JW, 1985. Meiofaunasediment interactions around subtropical seagrass sediments using factor analysis. J. Mar. Res. 43:237-255.

Dell'Anno A, Mei ML, Pusceddu A, Danovaro R, 2002. Assessing the trophic state and eutrophication of coastal marine systems: a new approach based on the biochemical composition of sediment organic matter. Mar. Pollut. Bull. 44:611-622.

Denny MW, Helmuth B, Leonard GH, Harley CDG, Hunt LJH, Nelson EK, 2004. Quantifying scale in ecology: lessons from a wave-swept shore. Ecol. Monogr. 74;513-532.

Fabiano M, Danovaro R, Fraschetti S, 1995. A three-year time series of elemental and biochemical composition of organic matter in subtidal sandy sediments of the Ligurian Sea (northwestern Mediterranean). Cont. Shelf. Res. 15:14531469.

Fleeger JW, Decho AW, 1987. Spatial variability of interstitial meiofauna: a review. Stygologia 3:35-54.

Fontaneto D, Hortal J, 2012. Microbial biogeography: is everything small everywhere?, p. 87-98. In: In: A. Lesley, R. Ogilvie and P. Hirsch (eds.), Microbial Ecological Theory - Current Perspectives. Caister Academic Press.

Fontaneto D, 2019. Long-distance passive dispersal in microscopic aquatic animals. Movem. Ecol. 7:10.

Gambi C, Pusceddu A, Benedetti-Cecchi L, Danovaro R, 2014. Species richness, species turnover and functional diversity in nematodes of the deep Mediterranean Sea: searching for drivers at different spatial scales. Global. Ecol. Biogeogr. 23:24-39.

Heip C, Vincx M, Vranken G, 1985. The ecology of marine nematodes. Oceanogr. Mar. Biol. 23:399-489.

Hewitt JE, McBride GB, Pridmore RD, Thrush SF, 1993. Patchy distributions: optimizing sample size. Env. Monit. Assess. 27:95-105.

Higgins RP, Thiel H, 1988. Introduction to the study of meiofauna. Smithsonian Institution Press, Washington, DC.

Jumars M, Thistle D, Jones M, 1977. Detecting twodimensional spatial structure in biological data. Oecologia 28:109-123.

Legendre P, Fortin MJ, 1989. Spatial pattern and ecological analysis. Vegetatio 80:107-138.

Levin LA, Sibuet M, 2012. Understanding continental margin biodiversity: a new imperative. Annu. Rev. Mar. Sci. 4:79112.

Lorenzen C, Jeffrey J, 1980. Determination of chlorophyll in seawater. Unesco Technical Paper in Marine Science no. 35. Unesco, Paris.

Moens T, Braeckman U, Derycke S, Fonseca G, Gallucci F, 
Ingels J, Leduc D, Vanaverbeke J, Van Colen C, Vanreusel A, Vinx M, 2013. Ecology of free-living marine nematodes, p. 109-152 In: A. Schmidt-Rhaesa (ed.), Handbook of zoology: Gastrotricha, Cycloneuralia and Gnathifera, vol. 2: Nematoda. De Gruyter, Berlin.

Montagna PA, Spies RB, 1985. Meiofauna and chlorophyll-a associated with Beggiatoa mats of a natural submarine petroleum seep. Mar. Environ. Res. 16:231-242.

Pinckney J, Sandulli R, 1990. Spatial autocorrelation analysis of meiofaunal and microalgal populations on an interdital sandflat: scale linkage between consumers and resources. Estuar. Coastal Shelf. Sci. 30:341-353.

Pratt D, Pilditch C, Lohrer A, Thrush S, Kraan C, 2015. Spatial distributions of grazing activity and microphytobenthos reveal scale-dependent relationships across a sedimentary gradient. Estuar. Coast. 38:722-734.

Pusceddu A, Bianchelli S, Canals M, Sanchez-Vidal A, Durrieu De Madron X, Heussner S, Lykousis V, de Stigter H, Trincardi F, Danovaro R, 2010. Organic matter in sediments of canyons and open slopes of the Portuguese, Catalan, Southern Adriatic and Cretan Sea margins. Deep-Sea Res. Pt I 57:441-457.

Pusceddu A, Bianchelli S, Gambi C, Danovaro R, 2011. Assessment of benthic trophic status of marine coastal ecosystems: significance of meiofaunal rare taxa. Estuarine Coastal Shelf. Sci. 93:420-430.

Pusceddu A, Dell'Anno A, Fabiano M, Danovaro R, 2004. Quantity and biochemical composition of organic matter in marine sediments. Biol. Mar. Medit. 11(S1):39-53.

Pusceddu A, Dell'Anno A, Fabiano M, Danovaro R, 2009. Quantity and bioavailability of sediment organic matter as signatures of benthic trophic status. Mar. Ecol. Progr. Ser. 375:41-52.

Pusceddu A, Dell'Anno A, Manini E, Fabiano M, Sarà G, Danovaro R, 2003. Enzymatically hydrolyzable protein and carbohydrate sedimentary pools as indicators of the trophic state of 'detritus sink' systems: a case study in a Mediterranean coastal lagoon. Estuaries 26:641-650.

Pusceddu A, Gambi C, Corinaldesi C, Scopa M, Danovaro R. 2014. Relationships between meiofaunal biodiversity and prokaryotic heterotrophic production in different tropical habitats and oceanic regions. PloS One 9(3):e91056.

Pusceddu A, Gambi C, Manini E, Danovaro R, 2007. Trophic state, ecosystem efficiency and biodiversity of transitional aquatic ecosystems: analysis of environmental quality based on different benthic indicators. Chem. Ecol. 23:1-11.

Raes M, De Troch M, Ndaro SGM, Muthumbi A, Guilini K, Vanreusel A, 2007. The structuring role of microhabitat type in coral degradation zones: a case study with marine nematodes from Kenya and Zanzibar. Coral Reefs, 26: 113-126.

Rex M, Etter KR, 2011. Deep-sea biodiversity: Pattern and scale. BioScience 61:327-328.

Sandulli R, Pinckney J, 1999. Patch sizes and spatial patterns of meiobenthic copepods and benthic microalgae in sandy sediments: a microscale approach. J. Sea Res. 41:179-187.

Semprucci F, Boi P, Manti A, Covazzi Harriague A, Rocchi M, Colantoni P, Papa S, Balsamo M, 2010. Benthic communities along a littoral of the Central Adriatic Sea (Italy). Helgol. Mar. Res. 64:101-115.

Sokal R, Oden N, 1978. Spatial autocorrelation in biology. II. Some biological implications and four applications of evolutionary and ecological interest. Biol. J. Linn. Soc. 10:229-249.

Sokal RR, Wartenberg DE, 1981. Space and population structure, p. 186-213. In: D. Griffith and R. McKinnon (eds.), Dynamic spatial models. Sijthoff and Noordhoff, Aphen aan den Rijn.

Thrush S, 1991. Spatial patterns in soft-bottom communities. Trends Ecol. Evol. 6:75-79.

Zeppilli D, Pusceddu A, Trincardi F, Danovaro R, 2016. Seafloor heterogeneity influences the biodiversity-ecosystem functioning relationships in the deep sea. Sci. Rep. 6:26352.

Warwick RM, Gee JM, Berge JA, Ambrose W, 1986. Effects of the feeding activity of the polychaete Streblosoma bairdi (Malmgren) on meiofaunal abundance and community structure. Sarsia 71:11-16.

Woolley S, Tittensor PD, Dunstan KP, Guillera-Arroita G, Lahoz-Monfort J, Wintle BA, Worm B, O'Hara T, 2016. Deep-sea diversity patterns are shaped by energy availability. Nature 533:393-396. 